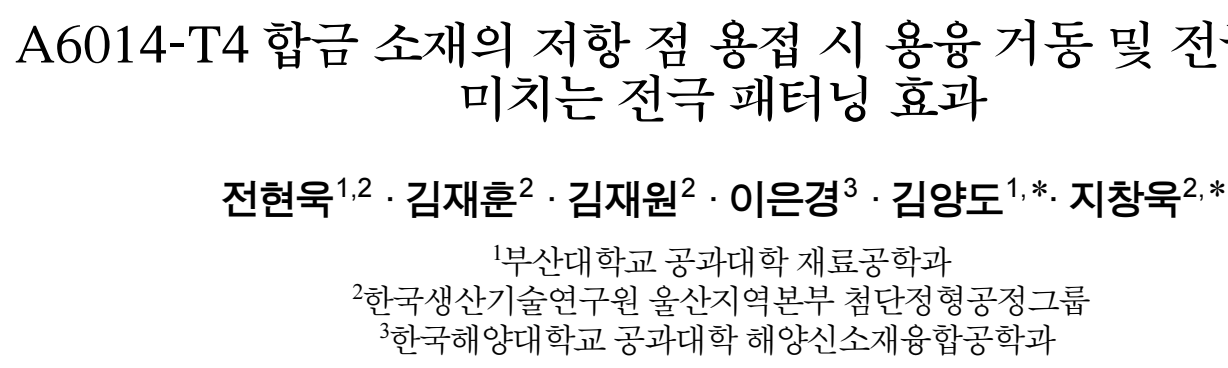

\title{
Effect of Electrode Patterning on Melting Behavior and Electrode Degradation in Resistance Spot Welding of A6014-T4 Alloy
}

\author{
Hyun-Uk Jun ${ }^{1,2}$, Jae-Hun Kim², Jae Won Kim², Eun-Kyung Lee ${ }^{3}$, Yang-Do Kim, ${ }^{1, *}$, and Changwook $\mathrm{Ji}^{2, *}$ \\ ${ }^{1}$ Department of Materials Science and Engineering, Pusan National University, Busan 46241, Republic of Korea \\ ${ }^{2}$ Ulsan Regional Division, Korea Institute of Industrial Technology, Ulsan. 44776, Republic of Korea \\ ${ }^{3}$ Department of Division of Mechanical Engineering, Korea Maritime \& Ocean University, Busan 49112, Republic of Korea
}

\begin{abstract}
In this study, the effects of electrode surface design on the resistance spot weldability and degradation of the electrode following resistance spot welding (RSW) of aluminum 6014-T4 alloy were investigated. A new patterning method that can be produced through repetitive pressurization was applied to the electrode, producing a lattice-like pattern shape on the resulting patterned electrode. When RSW was performed using the lattice patterned electrode, the contact resistance decreased because of the effective removal of the oxide film from the surface of the aluminum alloy. As a result, heat generated by resistance on the E/S interface was reduced. Moreover, the growth rate of the weld nuggets formed with the patterned electrode in the thickness direction was lower than that of the nuggets formed with the as-received electrode, and there was comparatively less $\mathrm{Cu}-\mathrm{Al}$ alloying of the patterned electrode. In addition, a continuous RSW process was performed on the alloy to observe the effect of the electrode surface design on electrode sticking. The results indicated that electrode surface shape can significantly influence resistance heat generation and electrode cooling effects, as well as produce welds with different weld morphology and microstructure. Finally, it was proved that the patterned electrode suffered less electrode degradation through EPMA on the electrode surface after the continuous RSW was completed.
\end{abstract}

(Received September 14, 2020; Accepted November 12, 2020)

Keywords: surface design, resistance spot welding (RSW), lattice-patterning, oxide film, cooling effects, electrode degradation

\section{1. 서 론}

세계적으로 온실가스 배출, 연료 경제에 대한 규정이 강 화됨에 따라, 자동차 산업분야에서는 연비 개선 및 환경문 제가 지속적으로 대두되고 있다 [1]. 온실가스 배출 저감

- 전현욱: 석사과정, 김재훈: 연구원, 김재원·지창욱: 박사, 이은경-김양도: 교수 *Corresponding Author: Changwook $J i$

[Tel: +82-52-980-6710, E-mail: cwji@kitech.re.kr]

${ }^{*}$ Co-corresponding author: Yang-Do Kim

[Tel: +82-51-510-2478, E-mail: yangdo@pusan.ac.kr]

Copyright (C) The Korean Institute of Metals and Materials
및 연비 향상을 위한 선제적 대응으로 차체 경량화 기술을 반드시 개발해야 한다. 일반적으로 자동차 무게의 $10 \%$ 가 감소하면 연비가 평균 $6.9 \%$ 향상될 수 있기 때문에 차체 경량화를 위해 알루미늄(Aluminum, Al), 마그네슘 (Magnesium, Mg), 탄소섬유 강화 복합재료(Carbon fiberreinforced plastic, CFRP) 등의 다양한 경량소재의 적용이 필요하다 [2,3]. 특히 알루미늄 합금 판재를 차체에 적용할 경우, 주철이나 강철(Steel)보다 전체 중량의 $40-60 \%$ 감소 하는 효과로 인하여 경제성 및 생산성 측면을 감안할 때, 다른 경량소재에 비하여 많은 장점을 지니고 있어 차체부 
품에 대한 적용 및 확대가 이루어지고 있는 실정이다 [4].

자동차 조립 공법 중 대표적인 저항 점 용접은 저비용, 높은 생산성, 견고성 등과 같은 장점을 가지고 있어 자동 차 차체의 주요 접합 공정으로 적용되고 있다. 알루미늄 합 금 판재의 저항 점 용접의 경우 열 및 전기 전도성이 높은 특성과 용접 시 집중된 응력 발생에 의한 열 변형에 따라 강재의 저항 점 용접보다 높은 용접전류(weld current)와 가압력 및 짧은 용접시간(weld time)의 공정조건, 그리고 평팁전극(flat type electrode)이 사용되어야 한다 [5].

또한 알루미늄 합금 판재는 높은 산화 특성으로 인해 표 면에 수 $\mathrm{nm}$ 두께의 불균일한 산화층을 형성시킨다 [6]. 이로 인하여 우수한 내부식-내마모성의 장점이 있으나, 저 항 점 용접 공정에서는 알루미늄 합금 판재 판재와 구리 (Copper, $\mathrm{Cu}$ ) 전극 계면 사이에 높은 발열을 야기시키는 원인으로 전극 표면 합금화, 전극열화, 비산형상, 표면 균 열 등의 문제를 발생시킨다. 특히 연속적인 저항 점 용접 공정에서는 $\mathrm{Cu}-\mathrm{Al}$ 합금화 현상으로 전극과 판재간의 융착 현상(sticking)이 반복되어, 전극 수명이 급격히 저하되고 양호한 품질의 용접부를 확보하기 어려운 실정이다. 따라 서 융착 및 전극 열화로 인한 품질문제를 개선하기 위해 알루미늄 합금 판재 저항 점 용접 공정에서는 드레싱 주기 를 강재보다 약 $1 / 6 \sim 1 / 8$ 배 짧게 하여 전극을 관리하고 있 다 $[7,8]$.

위에서 언급한 문제점들을 개선하기 위한 다양한 선행 연구들이 진행되었다. 소재적 측면에서는 Ronnhult 등[9]은 AA5052 소재의 저항 점 용접 공정 전에 $\mathrm{NaOH}$ 및 옥살 산으로 에칭하여 산화층을 제거하여 용접 품질이 개선되었 으나, 알루미늄 합금의 높은 산화성으로 인하여 산화층의 재발생 문제를 지적하였다. 또한 Rashid 등[10]은 $\mathrm{AA} 5185$ 소재 표면에 다양한 윤활제를 적용하여 특정 조합 에 대해 전극 수명이 약 $200 \%$ 향상되는 결과를 확인하 였다. 그리고 Chan 등[11]은 전극에 $\mathrm{TiC}$ 금속 성분을 코 팅하여 용접 로브 곡선이 상·하로 이동하고 적은 입열량으 로도 동일한 크기의 너겟이 형성되는 것을 확인하였고, $\mathrm{TiC}$ 코팅이 $\mathrm{Cu}-\mathrm{Al}$ 화에 대한 저항성을 증가시켜 전극과 판 재 사이의 국부 발열을 저감하여 전극 수명이 약 $70 \%$ 향상되는 효과를 발견하였다.

공정적 측면에서 살펴보면, Luo 등[12]은 AA5052 소재
에 예비 통전(pre-heating)을 적용하여 표면 산화층 안정화 에 대한 효과를 동저항 거동을 통해 분석하였고, 저항 점 용접의 반복성 및 일관성이 향상될 수 있음을 시사했다. 또한 Mueller 등[13]은 AW5182 소재의 저항 점 용접에 서 전극 표면에 연마와 같은 기계적 가공을 실시하여 전극 수명에 대해 연구하였다. 이 공법은 연속타점에 대한 용접 부 버튼 직경의 신뢰도를 향상시켰으나, 전극과 판재간의 합금화 현상을 완전히 제거가 어려웠고 연속타점 중간마다 추가 공정이 수행되는 문제를 지적하였다. 그리고 Deng 등 [14]은 AA6022-T4 소재의 저항 점 용접에서 전극 표면에 고리(ring) 형태의 패터닝된 전극(patterned electrode)과 기 존 일반전극(as-received electrode)으로 용접 시 기계적 특 성 및 미세조직 비교를 통해, 패터닝된 전극에서 용접성이 향상된다는 결과를 고찰한 바 있다. 이와 같이 선행 연구 들에 의해 알루미늄 합금 판재의 저항 점 용접을 개선하기 위한 다양한 공법들이 시도되고 있지만, 실용성 및 경제성 측면에서 전극 패터닝을 활용한 공법이 가장 중요시되고 있는 추세이다. 하지만 전극 패터닝에 따른 용융 거동 및 용접성 향상 효과의 원인에 대한 연구가 미흡하다.

본 연구의 목적은 $\mathrm{A} 6014-\mathrm{T} 4$ 합금 판재의 저항 점 용 접에서 모니터링 시스템을 활용한 전극 패터닝 유무에 따 른 산화층 제거에 대한 영향을 전기적, 열적 특성을 통해 간접적으로 분석하여 패터닝 효과를 명확하게 증명하고자 하였으며, 연속적인 용접 공정에서 전극 형상에 따른 용접 부 미세구조 및 전극 열화를 현미경과 전자탐침미량분석기 (EPMA)를 이용하여 용접성 비교·분석을 통해 고찰해보았다.

\section{2. 실험 방법}

본 연구에서 사용된 소재는 두께가 $1.6 \mathrm{~mm}$ 인 $\mathrm{T} 4$ 처리 된 A6014 합금이며, 합금조성은 표 1에 나타내었다. 용접 조건에 대한 변수는 ISO 18595:2007(E)에 준하여 최소 ' $5 \sqrt{\mathrm{t}}(\mathrm{t}=$ 판재의 두께 $)=6.324 \mathrm{~mm}$ ' 이상의 버튼 직경 을 만족하기 위해 가압력과 용접시간을 $5 \mathrm{kN}, 120 \mathrm{~ms}$ 로 설정하였고, 공정상의 안정화를 위해 초기가압시간(squeeze time)과 유지시간(hold time)은 $200 \mathrm{~ms}$ 로 동일하게 설정하 였다. 용접 전극은 직경 $20 \mathrm{~mm}$, 선단 반경(R) $100 \mathrm{~mm}$ 인 $\mathrm{Cu}-\mathrm{Cr}(3 \mathrm{wt} \%)$ 평팁 전극을 사용하였다.

Table 1. Chemical composition of A6014-T4.

\begin{tabular}{ccccccccccc}
\hline Alloy & \multicolumn{10}{c}{ Chemical composition (wt\%) } \\
\hline A6014-T4 & $\mathrm{Si}$ & $\mathrm{Fe}$ & $\mathrm{Cu}$ & $\mathrm{Mn}$ & $\mathrm{Mg}$ & $\mathrm{Cr}$ & $\mathrm{Zn}$ & $\mathrm{Ti}$ & $\mathrm{Al}$ \\
$(1.6 \mathrm{~mm})$ & 0.59 & 0.22 & 0.12 & 0.08 & 0.65 & 0.01 & 0.01 & 0.03 & $\mathrm{Bal}$. \\
\hline
\end{tabular}




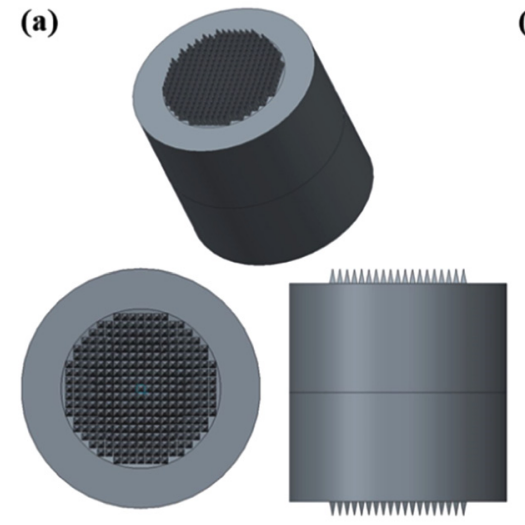

(b)

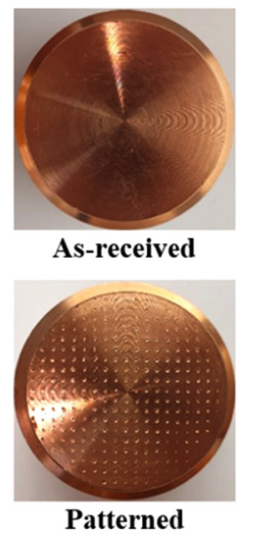

Fig. 1. Schematic press die and electrode surface image for electrode patterning process.

전극 패터닝 공법은 그림 1(a)와 같은 격자(lattice) 모양 의 형상으로 금형을 제작하여 반복 가압을 통해 구현하였 다. 이 공법은 구리소재의 낮은 표면경도를 고려한 것으로 제작된 금형을 사용하여 전극 표면에 균일한 표면상태를 확보하고자 하였다. 격자 모양의 패턴 형상을 사용한 이유 는 전극 표면에 인장 및 압축 변형을 교차로 발생시키는 지점을 극대화하기 위함이다 [13,14]. 그림 1(b)는 패터닝 유무에 따른 실제 전극의 표면형상이며, 격자 모양의 패턴 형상의 간격은 $1 \mathrm{~mm}$ 로 설정하였다.

용접 장비는 주파수 $1200 \mathrm{~Hz} \mathrm{MFDC}$ 저항 점 용접기에 서보모터 방식의 C type 건을 사용하였다. 전극 표면을 안 정화하기 위해 적정 용접조건에서 약 10 회 용접 후에 본 용접을 실시하였다. 전극 패터닝 유무에 따른 용접전류별 버튼 직경을 비교하기 위해, ISO 14270의 표준 규격에 따 라 시편을 제작하였다. 이때 각 용접조건에 대한 버튼 직 경은 파단 테스트(peel test)를 3회 실시 후 각각의 측정된 값에 대한 평균값이다.

저항 점 용접 공정 전에 전극 패터닝 유무에 따른 접촉 저항을 측정하기 위해, 그림 2 와 같이 디지털 옴미터 (digital ohmmeter) 장비로 20 회씩 측정하였다. 이때 전극 간의 가압을 통한 초기 접촉저항의 안정화 작업을 실시한 후에, 알루미늄 합금 판재의 벌크저항(bulk resistance) 값 을 배제하여 접촉저항(contact resistance) 값만 비교하였다. 측정 기준은 ISO 18594:2007(E)를 바탕으로 가압력을 5.5 $\mathrm{kN}$, 전류를 $10 \mathrm{~A}$ 로 설정하였다. 전극 패터닝 공법에 따른 점용접성 차이의 원인규명을 위하여 동저항을 비교·분석해 보았다. 동저항 값은 전극 양 선단에 장착한 계측장비를 통해 실시간으로 측정한 전압과 전류를 계산하여 측정하였 고, 용접시간에 대해 $0.02 \mathrm{~ms}$ 단위로 값을 추출하여 나타

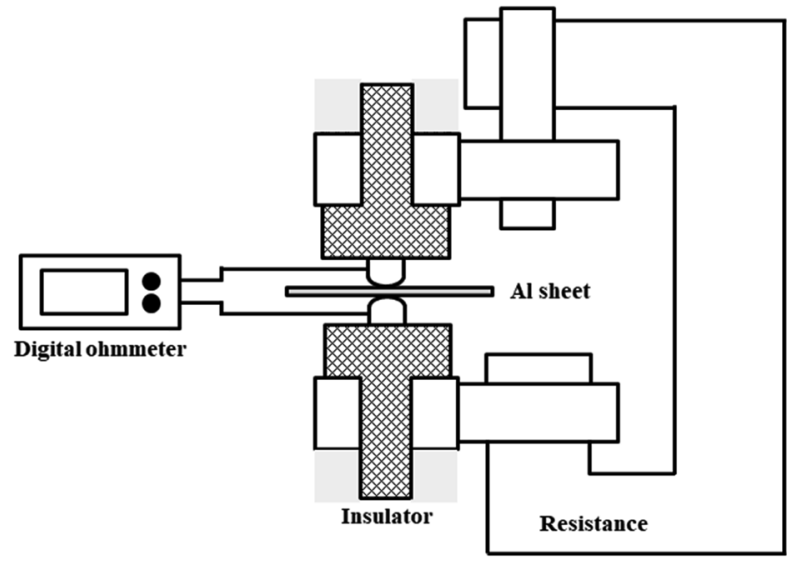

Fig. 2. Setup for contact resistance measurement.

내었다.

저항 점 용접 공정 시 열화상 카메라를 사용하여 전극판재간 계면(E/S surface), 판재-판재간 접합계면(faying surface)의 발열현상을 비교 관찰하였고, 이때 알루미늄 합 금의 특성 및 열 분포를 고려하여 카메라의 방사율은 0.2 설정하였다 [1]. 저항 점 용접의 특성을 고려하여 카메라의 각도 및 밀폐된 용접부의 절대적인 온도를 측정하기 어려 워 알루미늄 합금 판재의 융점을 기준으로 상대적인 온도 에 대한 변화를 열 강도(thermal intensity)로 나타내어 비 교·분석하였다.

일반전극과 패터닝된 전극을 이용한 용접부 미세구조 및 전극 표면의 합금성분을 분석하기 위해서 광학 현미경 (Optical Microscope, OM)과 주사 전자현미경(Scanning Electron Microscope, SEM), 그리고 전자탐침미량분석기 (Electron Probe Micro-Analysis, EPMA)를 사용하였다. 이때 전극과 판재의 기준 및 합금성분을 고려하여 $\mathrm{Cu}, \mathrm{Al}$, $\mathrm{Si}, \mathrm{Fe}, \mathrm{O}$ 각각의 성분들에 대한 분석을 진행하였고, $20 \mathrm{keV}, 100 \mathrm{nA}, 400 \times 400$ 분해능의 분석조건으로 $8.6 \times 8.6 \mathrm{~mm}$ 영역을 이미지화하였다.

\section{3. 실험결과 및 고찰}

\section{1 전극 패터닝 유무에 따른 용접 버튼 직경 비교}

본 연구에서는 전극 패터닝 유무에 따른 용접특성을 분 석하기 위해, 동일 용접전류를 인가하여 용접특성을 비교 하기보다는 유사한 용접부 버튼 직경을 갖는 용접조건을 선저하여 실험에 적용하였다 $[13,14]$. 따라서 규격에서 요 구하는 최소 버튼 직경인 ' $5 \sqrt{\mathrm{t}}(\mathrm{t}=$ 판재의 두께 $)=$ $6.324 \mathrm{~mm}$ '를 기준으로 특성을 비교하였다 [4]. 그림 3는 


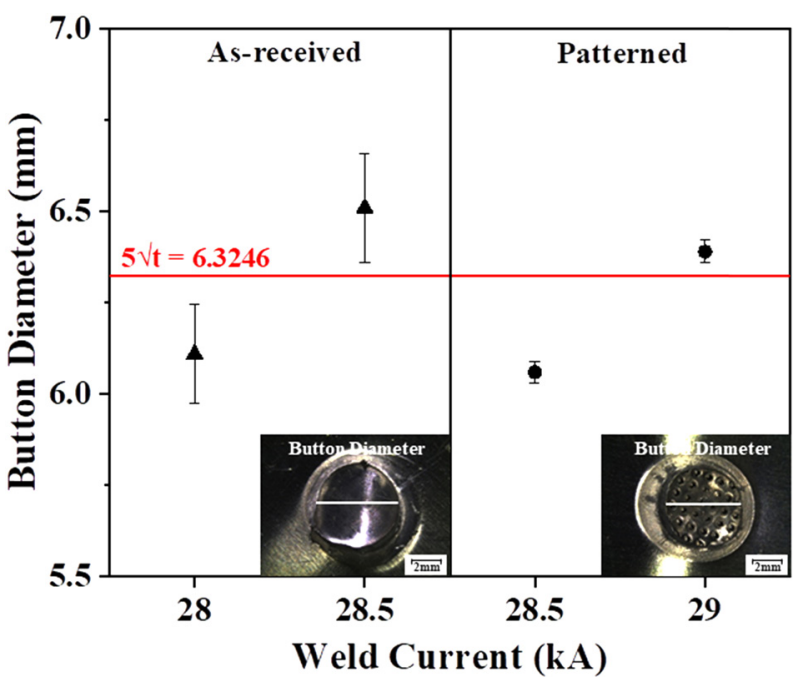

Fig. 3. Button diameter with respect to the electrode surface design for changing weld current.

전극 패터닝 유무에 따른 용접전류와 버튼 직경 변화를 나 타낸 결과이다. 일반전극을 사용한 경우에는 용접전류 $28.5 \mathrm{kA}$ 에서 평균 $6.49 \mathrm{~mm}$ 로 최소 임계 버튼 직경을 만족 하였으며, 패터닝된 전극에서는 $29 \mathrm{kA}$ 에서 평균 $6.39 \mathrm{~mm}$ 로 만족하였다. 패터닝된 전극을 사용한 경우에 동일 용접 조건에 대해서는 용접부 버튼 직경의 크기는 더 작았으나, 측정 편차는 더 균일하였다.

\section{2 모니터링 시스템을 통한 전기적, 열적 특성 분석}

\subsection{1 접촉저항 측정}

알루미늄 합금 판재에 대한 접촉저항은 표면 산화층으로

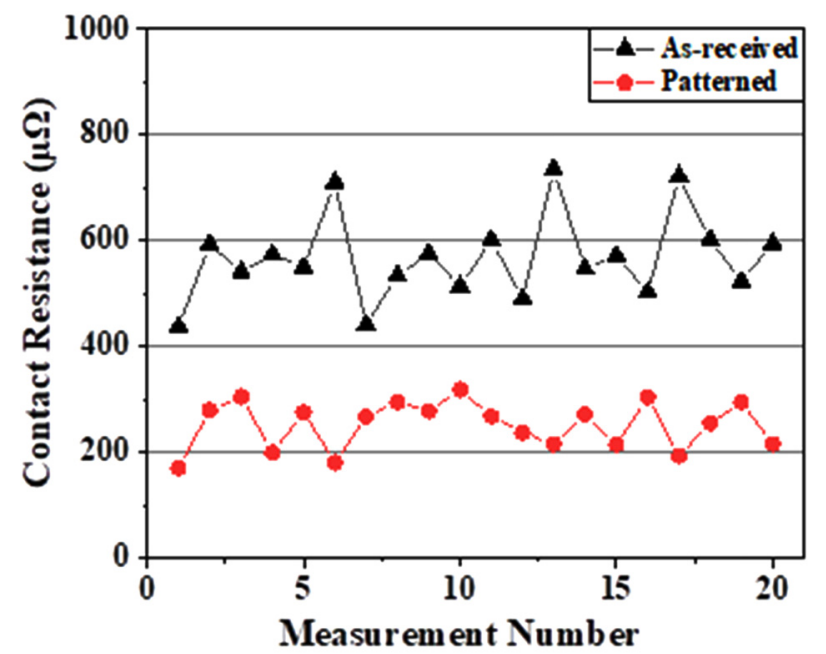

Fig. 4. Electrical contact resistance of E/W interface of A6014-T4 (about 20 measurement).
인해 평균적으로 약 400-800 $\mu \Omega$ 수준으로 알려져 있다 [15]. 그림 4는 전극 형상에 따른 초기 접촉저항 차이를 나타낸 결과이다. 두 전극에 대해 20 회씩 측정결과, 일반 전극의 접촉저항은 최대 $735.4 \mu \Omega$ 최소 $437.4 \mu \Omega$ 이였으 며, 패터닝된 전극의 경우는 최대 $304.6 \mu \Omega$, 최소 170.4 $\mu \Omega$ 이였다. 또한 일반전극에서는 약 $568.5 \mu \Omega$ 의 평균값과 $81.6 \mu \Omega$ 의 표준 편차를 가졌으며, 패터닝된 전극에서는 $252.8 \mu \Omega$ 과 $45.3 \mu \Omega$ 의 평균값과 표준 편차로 측정되었다. 즉, 패터닝된 전극에서 패터닝된 전극의 접촉저항이 일반 전극보다 평균 2 배 가량 낮았으며, 측정 편차도 적었다. 이 는 격자 모양의 패턴 형상이 전극과 판재의 계면에 인장 및 압축 변형을 교차로 발생시켜 산화층 붕괴(break-down) 로 인해 넓은 통전면적을 확보하였기 때문이다 $[14,16]$. 따 라서 알루미늄 판재 표면에 불균일한 형태로 존재하는 산 화층이 전극 패터닝에 의해 접촉초기부터 붕괴됨으로써 안 정적인 통전면적을 확보하였기 때문에 접촉저항 측정 편차 뿐만 아니라, 버튼 직경의 측정 편차도 작아진 것으로 사 료된다.

\subsection{2 동저항 거동 분석}

저항 점 용접 공정 중 발생하는 저항은 전극과 판재의 고유 벌크저항과 판재와 전극, 판재와 판재의 접합계면에 서 발생하는 접촉저항으로 나누어지며, 용접시간에 따른 두 합산 저항 값을 동저항이라고 정의한다. 용접이 진행되는 동안에 동저항 곡선은 초기 용접시간의 접촉거동부터 용접 이 종료되기 전까지의 용융현상을 이해하는데 필수적 요소 이다 $[16,17]$. 특히 알루미늄 합금의 고유 특성으로 인하여 전체 용접시간에 대한 용융현상의 비교 및 고찰은 어렵지 만, 초기 용접시간 동안 접촉 및 산화층 거동에 대한 차이 는 간접적으로 유추할 수 있다. 그림 5 는 패터닝 유무에 따른 동저항 거동을 비교한 결과이다. 전체적인 동저항 곡 선은 $20 \mathrm{~ms}$ 까지 저항값이 감소하다가 이후에는 유사한 선 형거동을 보였다. 이는 알루미늄 합금의 고유특성인 낮은 벌크저항 및 융점과 온도상승에 따른 전기 전도도의 증가 로 인하여 $20 \mathrm{~ms}$ 이후부터 용접종료시점까지 저항 값의 상승이 미비하였다고 판단된다 [16]. 용접초기에 저항은 산 화층의 영향이 매우 크다. 용접이 진행되면 저항값이 감소 하게 되는데, 이는 입열에 의하여 표면 산화층이 붕괴되기 때문이다.

용접시간이 $20 \mathrm{~ms}$ 에서는 두 전극의 저항 값이 약 123 $\mu \Omega$ 으로 유사하였으나, 동저항 곡선의 초기값은 일반전극 의 경우 약 $714 \mu \Omega$ 패터닝된 전극에서는 약 $412 \mu \Omega$ 으로 약 $1 / 3 \sim 1 / 2$ 정도의 차이가 발생하였다. 이는 격자 모양의 


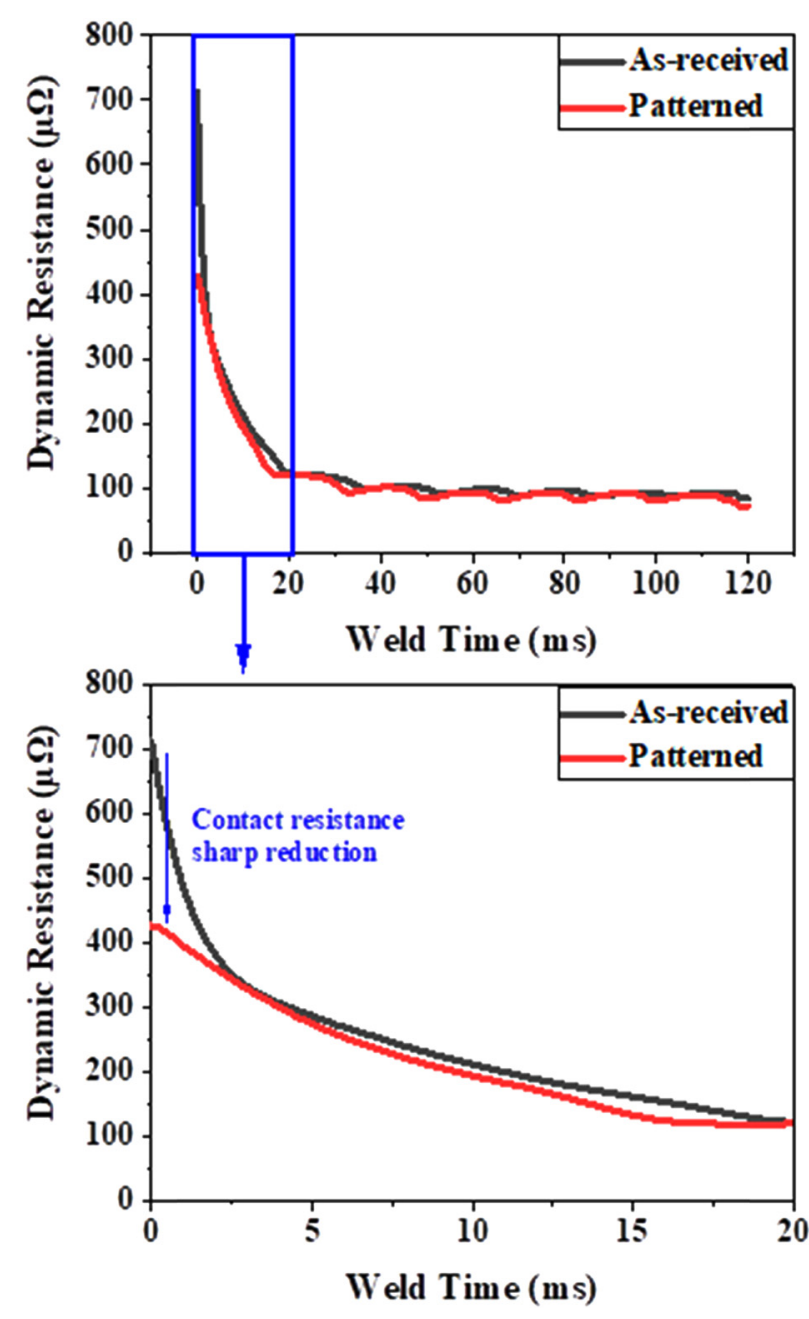

Fig. 5. Dynamic resistance curve at the first weld count by electrode surface design.

패턴 형상이 접촉저항을 감소시켰다는 것에 대한 근거로서 [17], 패터닝된 전극에서 알루미늄 합금 판재의 산화층 붕 괴와 동시에 통전면적이 확장되었다는 간접적 증거이다. 즉, 패터닝된 전극의 사용은 전극-판재간 계면의 접촉저항 을 줄였기 때문에 동저항 곡선을 변화시켰고, 이는 용접 중 입열량에 의한 최대온도와 발열 특성에 영향을 미칠 것 으로 사료된다.

\section{2 .3 용접시간에 따른 온도 분포}

그림 6 은 열화상 카메라를 활용하여 각 계면에 대한 온 도 분포를 비교하여 나타내었다. 그림 $6(\mathrm{a})$ 의 모식도와 같 이 패터닝 유무에 따른 접합계면의 온도 분포를 그림 6(b), (c)에 각각 나타내었다. 두 전극에 대해 동일한 온도 level로 비교한 결과, 패터닝 유무에 관계없이 판재-판재간 접합계면이 가장 높은 온도 분포를 보였으며, 전극-판재간

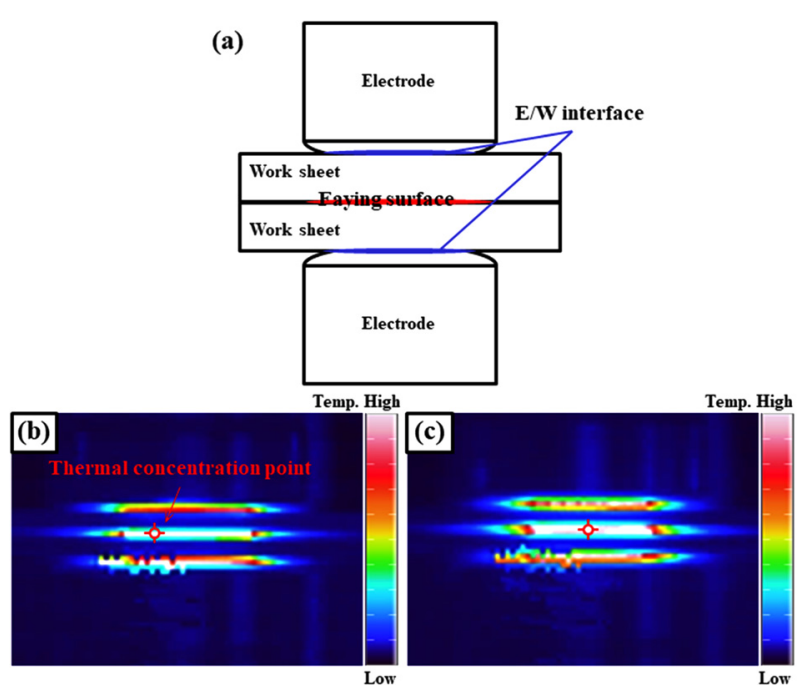

Fig. 6. The comparison of thermal distribution at the end of the weld time for electrode surface design; (a) Schematic of (b) asreceived, (c) patterned.

계면에 대해서는 패터닝된 전극이 상대적으로 낮은 온도 분포로 관찰되었다.

그림 7은 두 전극에 대해 시간에 따른 최대온도 변화를 나타낸 결과이다. 전극-판재간 계면과 판재-판재간 접합계 면에 대한 온도를 1 cycle 간격으로 측정한 결과, 총 용접 시간(통전+유지시간)동안 일반전극에서는 전극-판재간 계 면의 최대온도는 판재-판재간 접합계면의 약 0.8 배 수준이 었다. 동일한 용접조건으로 저항 점 용접 해석 시뮬레이션 $\mathrm{SORPAS}^{\circledR}$ 결과에서도 전극-판재간, 판재-판재간 접합계면 최대온도는 각각 $502.8^{\circ} \mathrm{C}, 638.5^{\circ} \mathrm{C}$ 로 유사한 수준을 보였 다. 그림 7(a)의 경우, 총 용접시간에 대한 최대온도는 일 반전극이 패터닝된 전극보다 높았다. 접촉저항 및 동저항 결과와 연계하여, 이는 패터닝된 전극에서 산화층 붕괴로 인 해 전극-판재간 계면의 접촉저항이 감소하였기 때문이다. 그 림 7(b)에서는 통전시간 동안 온도 상승속도가 패터닝된 전극에서 더 빨랐으며, 유지시간의 경우도 마찬가지로 온 도 감소속도는 패터닝된 전극에서 더 빨랐다. 하지만 통전 시간이 종료된 시점에서의 최대온도는 패터닝 유무에 관계 없이 유사하였다. 즉, 총 용접시간 동안 패터닝된 전극에서 더욱 급격한 온도 변화가 발생하였으며, 이는 전극-판재간 계면에서 통전면적이 확장되어 전류밀도 감소 및 국부적인 발열 현상이 저감되었기 때문이다. 따라서 패터닝된 전극 에서 전극-판재간 계면의 발열은 낮았고, 입열이 판재-판재 간 접합계면에 집중되었기 때문에 유지시간 동안 냉각수 순환에 따른 냉각 효과가 높았다고 판단된다 [16]. 
(a)

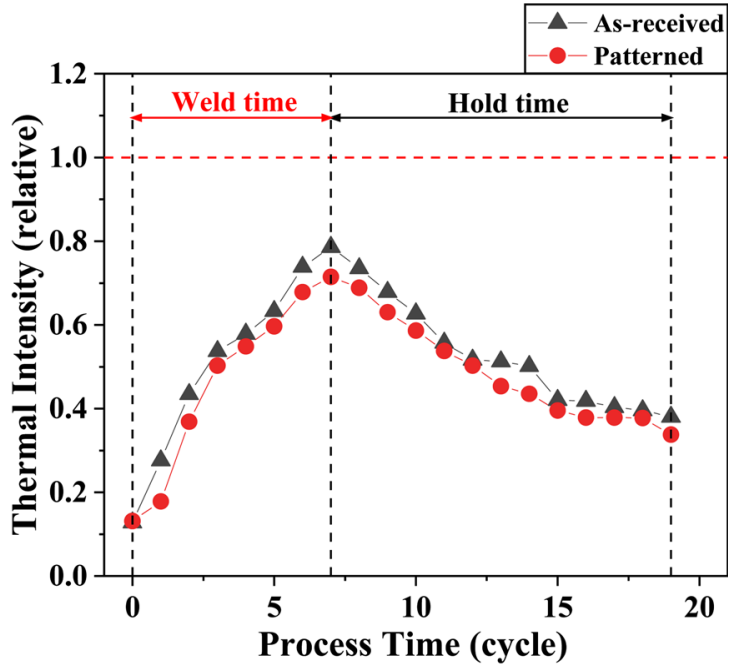

(b)

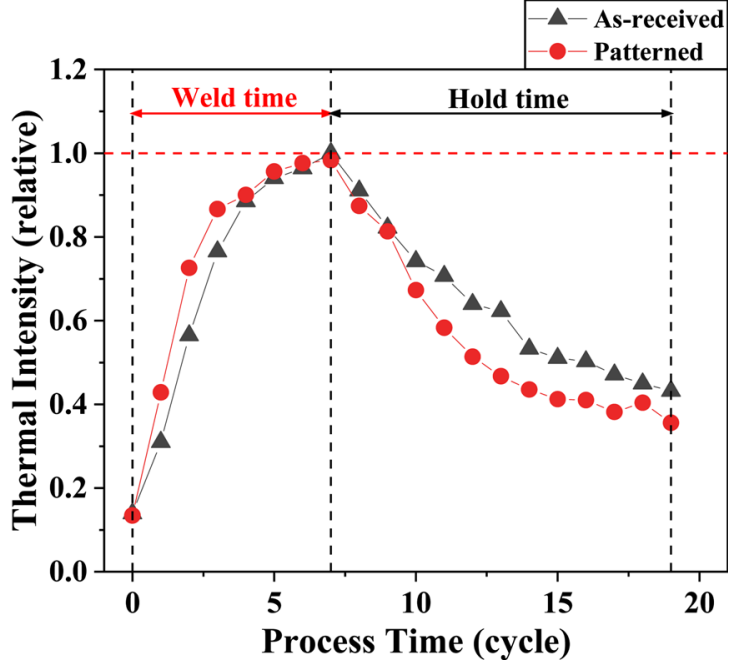

Fig. 7. The relative temperature comparison according to the process time at the each interface; (a) E/W surface, (b) faying surface (about 1 cycle $=16.7 \mathrm{~ms}$ ).

\section{3 전극 패터닝 유무에 따른 용접부 미세구조}

\subsection{1 용접부 단면}

그림 8는 전극 패터닝 유무에 따른 최소 임계 버튼 직 경을 만족하는 용접조건에서 용접부 단면을 비교한 결과이 다. 그림 $8(\mathrm{a})$ 의 일반전극을 사용한 용접부 너겟의 형상이 상, 하부 비대칭현상이 크게 발생하였고, 그림 $8(\mathrm{~b})$ 의 패터 닝된 전극을 사용한 경우도 판재 끝에서부터 너겟의 형상 위치가 하부 쪽에 분포하였다. 이는 직류 용접기에서 나타 나는 펠티어(Peltier) 효과로써, $(+)$ 극의 하부 전극과 맞닿 은 하부 판재부에 더 높은 열이 집중되었고, 전극-판재간 계면의 접촉저항이 상대적으로 높은 일반전극에서 펠티어 효과가 가속화되었다고 판단된다 [18]. 또한 패터닝된 전

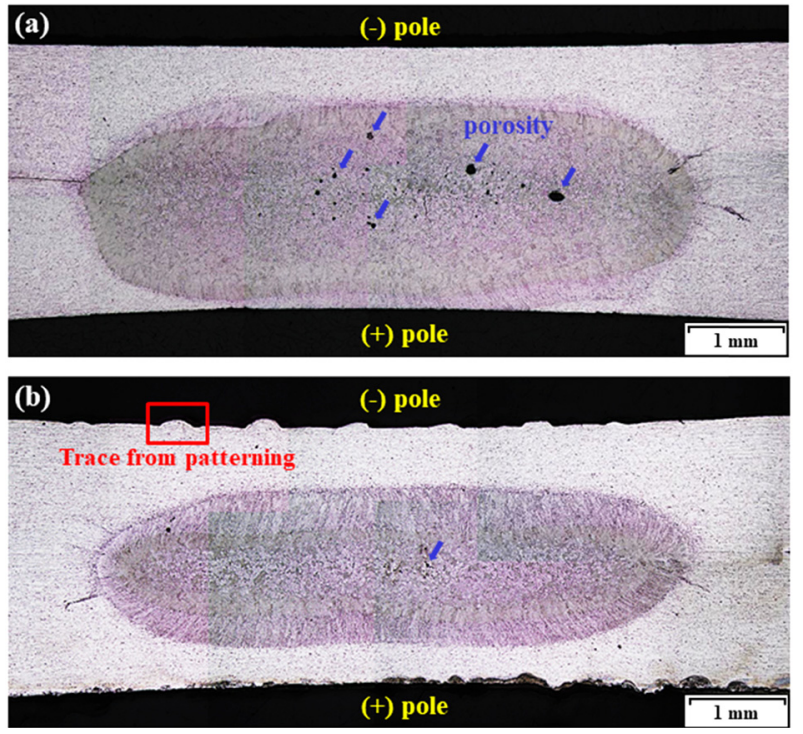

Fig. 8. Cross-section at the first weld spot with respect to the electrode surface design; (a) as-received, (b) patterned.

극에서 일반전극보다 기공과 같은 용접결함이 현저하게 적 은 모습을 보였는데, 이는 패터닝된 전극이 격자모양의 패 턴형상으로 인해 동일한 가압에 대하여 전극과 판재의 압 착된 힘이 더 크게 작용하였기 때문이다 [19].

전극 패터닝 유무에 따른 용접부의 너겟경은 그림 8(a), (b)에 대해 각각 $6.45,6.31 \mathrm{~mm}$ 로 상대적으로 높은 전류조 건 $(0.5 \mathrm{kA})$ 에서 패터닝된 전극을 사용한 경우에 비하여 용 접부의 너겟 직경이 다소 작았으며, 너겟의 전체 면적은 일반전극을 사용한 경우가 훨씬 더 크게 관찰되었다. 그림 8 의 결과에서는 동일한 통전시간에 대해 더 높은 용접전류 값의 패터닝된 전극으로 생성된 용접부 너겟의 크기와 면 적이 감소하였다. 일반적으로 저항 점 용접 시의 입열량이 클수록 너겟의 크기 및 면적이 증가하는 경향이 있다 [20]. 따라서 격자 모양의 패턴 형상에 따른 저항 특성의 차이는 용접 시 입열량에 변화를 가져온 것으로 판단된다. 기본적으로 저항 점 용접에서의 입열량에 대한 계산식은 식 (1) 과 같다.

$$
\mathrm{Q}=\mathrm{I}^{2} \cdot \mathrm{R} \cdot \mathrm{t}
$$

여기서 $\mathrm{Q}$ 는 입열량 $(\mathrm{J}), \mathrm{I}$ 는 용접전류(kA), R 은 저항 $(\mu \Omega)$, 그리고 $\mathrm{t}$ 는 통전시간 $(\mathrm{sec})$ 이다. 앞서 그림 5 에서 확인한 동저항 곡선을 이용하여 일반전극과 패터닝된 전극 으로 용접 시의 R·t 값에 대해 각각 계산할 수 있다. 그 림 9에 나타난 모식도를 활용하여 두 전극에 대한 R·t 값 


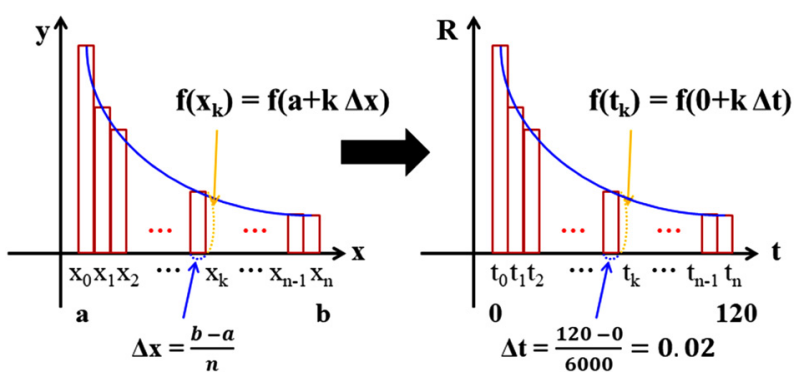

Fig. 9. Schematic diagram of the integral of the dynamic resistance curve for $\mathrm{R} \cdot \mathrm{t}$ calculation.

을 구하는 계산식은 아래의 식 (2)와 같다.

$$
\sum_{\mathrm{k}=1}^{\mathrm{n}} \mathrm{f}\left(\mathrm{a}+\frac{\mathrm{b}-\mathrm{a}_{\mathrm{n}}}{\mathrm{n}} \mathrm{k}\right) \cdot \frac{b-a}{n} \rightarrow \sum_{k=1}^{6000} f(0+k \cdot \Delta t) \cdot \Delta t
$$

두 전극으로 용접 시의 R·t 값은 식 (2)에 대해 일반전극 에서는 $14635 \mu \Omega \cdot \mathrm{ms}$, 패터닝된 전극에서는 $13565 \mu \Omega \cdot \mathrm{ms}$ 로 계산되었다. 두 전극에 대해 사용된 각각의 용접전류와 동저항 곡선에 대한 $\mathrm{R} \cdot \mathrm{t}$ 값을 식 (1) 대입한 결과, 일반전 극에서의 입열량은 $11887 \mathrm{~kJ}$, 패터닝된 전극에서는 $11408 \mathrm{~kJ}$ 로 일반전극에서 입열량이 높았다. 전극 패터닝 유 무에 유사한 버튼 직경을 갖는 용접조건의 경우 일반전극 이 $0.5 \mathrm{kA}$ 낮았지만, 결과적으로 식 (1)에 기초하여 패터닝 된 전극에 의한 접촉저항의 감소가 용접전류의 증가보다 큰 영향을 주었기 때문에 패터닝된 전극을 사용한 경우 입 열량이 낮았다.

\subsection{2 용접부 미세구조}

일반적으로 알루미늄 합금의 저항 점 용접부의 미세조직 은 모재(base metal; BM), 열영향부(heat affected zone; HAZ), 용접부(fusion zone; FZ), 3 가지로 분류된다. 용접 부의 미세구조 크기/종류는 합금 성분과 열 이력에 의해 결 정되며, 이는 용접 공정상에서 온도 구배(thermal gradient) 및 과냉도와 직접적으로 관련이 있다 [21]. 그림 10 은 미세 조직별 종류와 영역 크기를 나타낸 결과이다. 일반전극(그림 10(a))과 패터닝된 전극(그림 10(b))에서 모두 모재에서 너 겟의 중심까지 최종적으로 응고된 결정 영역은 4 개의 미 세구조 영역(부분 용융 영역(partially melting zone; $\mathrm{PMZ}$ ), 조대 수지상 영역(coarse columnar zone; $\mathrm{CCZ}$ ), 미세 수지상 영역(fine dendritic zone; FDZ) 및 등축정 영역(equiaxed zone; EZ))으로 종류는 동일하였으나, 각 영역들의 분포는 다른 특성을 보였다 [14,22].

그림 $10(\mathrm{a}),(\mathrm{b})$ 모두 $\mathrm{PMZ}$ 영역은 좁고 경계가 불분명하 였으며, 이는 낮은 용융점과 높은 열전도도의 고유특성을
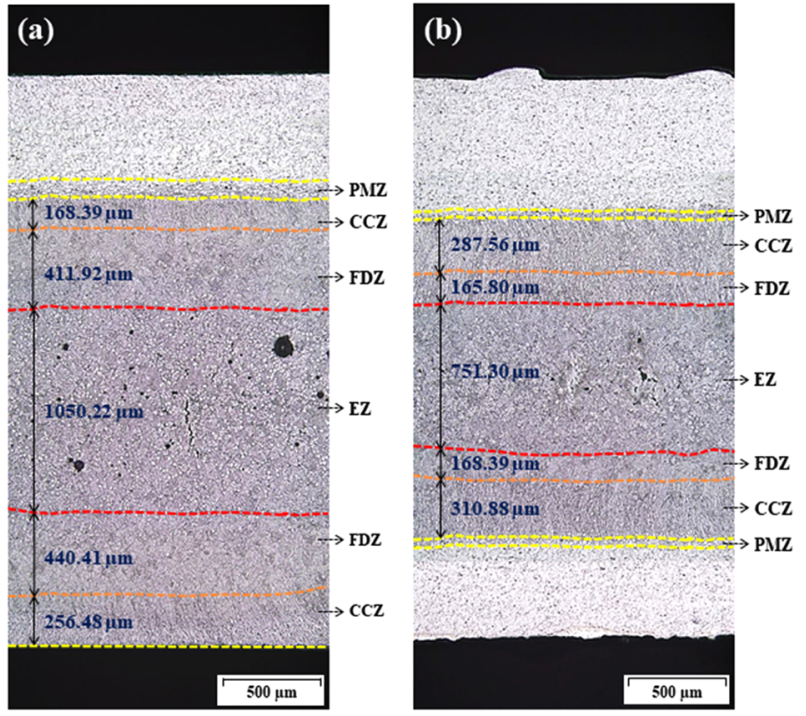

Fig. 10. Weld nugget microstructures for patterned electrode surface design. The weld nugget zones identified are the following: partially melted zone (PMZ), coarse columnar zone (CCZ), fine dendritic zone (FDZ), and equiaxed zone (EZ).

가지는 알루미늄 합금 용접부의 일반적인 특징이다 $[5,14]$. 그림 $10(\mathrm{a})$ 의 경우, $\mathrm{CCZ}, \mathrm{FDZ}$ 및 $\mathrm{EZ}$ 의 두께는 각각 약 $424.54 \mu \mathrm{m}, 852.33 \mu \mathrm{m}, 1050.22 \mu \mathrm{m}$ 로 전체 면적에 대 해 약 $0.18: 0.37: 0.45$ 의 비를 가졌으며, 그림 $10(\mathrm{~b})$ 에서는 각각 약 $598.44 \mu \mathrm{m}, 334.19 \mu \mathrm{m}, 751.30 \mu \mathrm{m}$ 로 측정되었고 약 $0.36: 0.19: 0.45$ 의 비를 가졌다. 일반 전극과 패터닝된 전극으로 생성된 용접부의 $\mathrm{EZ}$ 는 유사하 였으나, $\mathrm{CCZ}$ 와 $\mathrm{FDZ}$ 의 분포는 달랐다.

그림 11은 두 전극으로 생성된 용접부의 미세구조를 영 역별로 비교한 결과이다. 그림 $11(\mathrm{a}),(\mathrm{e})$ 는 $\mathrm{PMZ}$ 로 다른 영역에 비해 상대적으로 큰 재결정 입자로 구성되었다. 이 영역은 열영향부와 용접부의 경계가 되는 지점으로써, 일 반적으로 입열량에 비례하여 형성된다 [22]. PMZ는 그림 11(a)가 그림 11(e)보다 약 2배 정도 넓었으며, 재결정된 입자의 분포가 훨씬 많이 관찰되었다. 이는 패터닝된 전극 이 전극-판재간 계면에서의 접촉저항을 감소시켜 저항 점 용접 시 일반전극보다 적은 입열량을 가졌기 때문이다.

그림 $11(\mathrm{~b}),(\mathrm{f})$ 와 같은 $\mathrm{CCZ}$ 는 용접부의 경계의 인접해 서 분포하였고, 전극의 압흔 면적의 증가에 따른 전류 밀 도의 감소로 인하여 너겟의 성장의 끝부분에서 냉각방향(전 극)으로 응고가 진행되면서 생성된다 $[23,24]$. 이때 얕은 온 도 구배로 인하여 남아있는 액상의 용융지 내로 거친 기둥 형 구조를 형성하였다. 전극 패터닝 유무와 관계없이 $\mathrm{CCZ}$ 안쪽 영역에는 그림 $11(\mathrm{c}),(\mathrm{g})$ 와 같은 $\mathrm{FDZ}$ 가 형성되었다. 

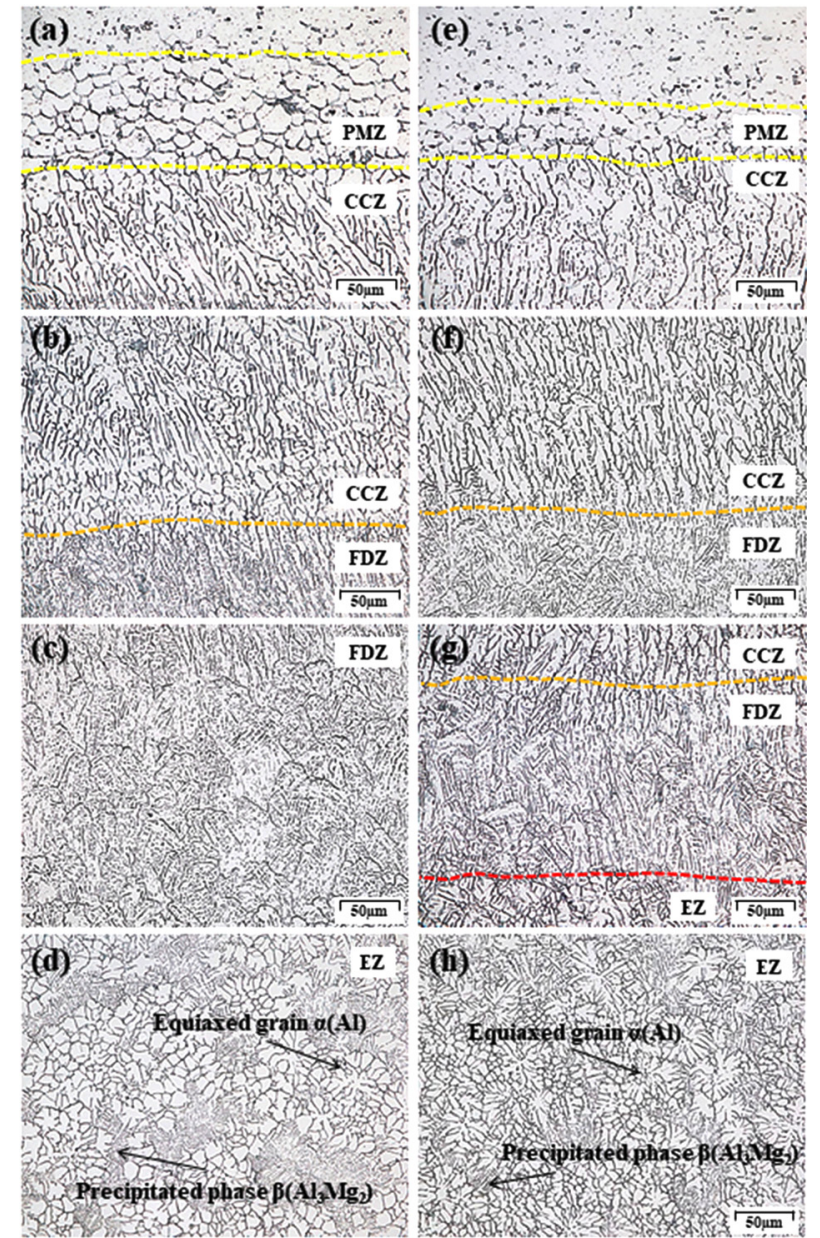

Fig. 11. Microstructures of A6014-T4 alloy resistance spot welding; (a)-(d) : as-received, (e)-(f) : patterned.

이 영역은 용접전류 통전이 종료된 후에 용접 전극의 냉각 효과와 용융 영역 사이에 가파른 온도 구배를 통해 형성되 며, 세밀하고 단단한 수지상 구조의 형태를 가지는 특징이 보편적이다 [21,22]. 그림 10 에서 확인한 수지상 영역의 분포와 같이 $\mathrm{FDZ}$ 는 일반전극보다 패터닝된 전극에서 작 게 형성되었다. 이는 전극 패터닝 유무에 따른 발열현상 및 용접시간 동안 통전면적 차이에 저항 특성으로 최대온 도 값이 달랐고, 유지시간 동안의 전극의 접촉에 의한 냉 각속도 차이를 유도하였기 때문인 것으로 판단된다. 즉, 패 터닝된 전극으로 용접 시에 낮은 입열량 및 빠른 냉각속도 로 인한 응고전면의 얕은 온도 구배가 형성되었기 때문에 초기에 수지상 형성이 가속화되었다고 판단된다 $[14,22]$.

최종적으로 용접 종료 후, 응고가 진행되면서 수지상 간 의 충돌이 발생하였고, 이후 남은 액상에서 등축 결정립의 핵 형성으로 인하여 수지상에서 등축정으로의 전이
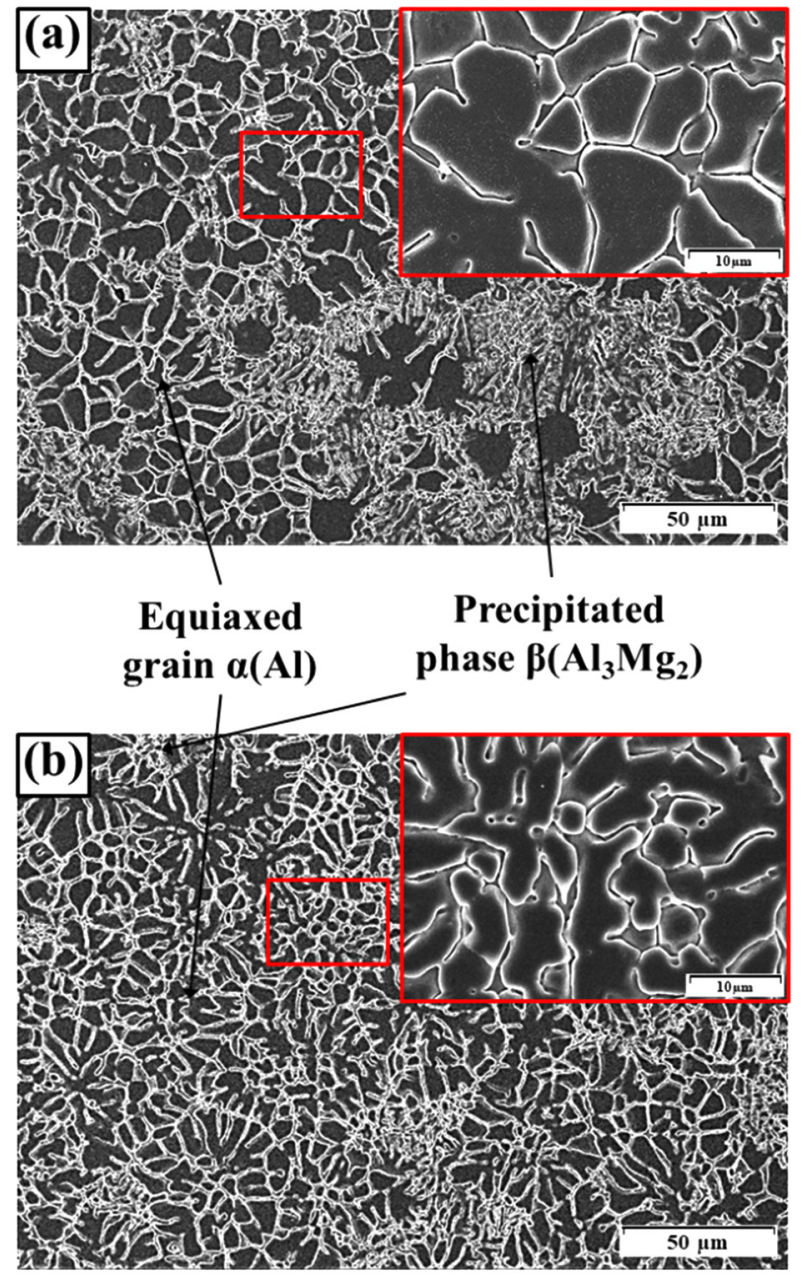

Fig. 12. Equiaxed zone (EZ) in weld nugget microstructures for electrode surface design; (a) : as-received, (b) : patterned.

(columnar to equiaxed transition, $\mathrm{CET}$ ) 로 인하여 그림 $11(\mathrm{~d}),(\mathrm{h})$ 와 같은 $\mathrm{EZ}$ 가 형성되었다. 이 영역은 $\mathrm{CCZ}$, $\mathrm{FDZ}$ 에서 밀려난 합금 성분으로 인해 합금 함량이 더 높은 경향이 있으며, 침전된 상인 2 차상 $\left(\beta\right.$ 상 $\left(\left(\mathrm{Al}_{3} \mathrm{Mg}_{2}\right)\right)$ 을 포함 하는 구조를 나타내었다 [14,22]. 또한 그림 11(h)과 같이 패터닝된 전극에서 더 미세한 등축 결정립을 보였으며, 침 전된 상의 형태인 2 차상의 분포도 감소하였다. 그림 12 는 $\mathrm{EZ}$ 만을 고배율에서 관찰한 결과로 패터닝된 전극(그림 $12(\mathrm{~b}))$ 의 평균 등축 결정립 크기는 약 $22.6 \mu \mathrm{m}$ 로 측정되었 으며, 이는 일반전극(그림 12(a))에서 측정된 평균 크기(약 $38.8 \mu \mathrm{m})$ 보다 약 $58.2 \%$ 더 작았다 [22]. 응고 이론에 따르 면 온도 구배의 감소는 조성적 과냉도(constitutional supercooling)의 증가로 이어져 등축 결정립 형성을 촉진하 며, 침전된 상인 2 차상의 분포와 크기는 감소한다고 알려 져 있다 [22,24]. 앞서 3.2 절의 전기적/열적 특성과 연계 
하면 패터닝된 전극을 사용한 경우 전극-판재간 계면의 통 전면적이 확장되어 전류밀도 감소 및 국부적인 발열 현상 이 저감되었기 때문에 빠른 냉각 속도로 인한 온도 구배의 감소가 원인으로 판단된다 $[21,25]$. 결과적으로 일반전극과 패터닝된 전극으로 생성된 용접부 미세구조는 냉각 효과에 따른 응고 속도의 차이로 인하여 빠른 냉각 속도가 가능한 패터닝된 전극에서 더 미세하고 치밀한 결정립이 형성되었 으며, 2차상의 분포는 감소하였다.

\section{4 연속타점에 따른 전극과 판재의 융착현상}

\subsection{1 전극과 판재의 표면 오염 및 초기 동저항 비교}

Lum 등[7]의 선행 연구에 따르면, 일반적으로 알루미늄 합금 판재의 저항 점 용접에서는 산화층으로 인해 첫 번째 타점에서부터 전극-판재간 계면에서 알루미늄 픽업( $\mathrm{Al}$ pick-up)현상이 흔하게 발생한다고 보고되어있다. 또한 연 속적인 저항 점 용접에서 $\mathrm{Cu}-\mathrm{Al}$ 합금화(주로 $\mathrm{CuAl}_{2}$ 및 미량의 $\mathrm{Cu}_{9} \mathrm{Al}_{4}$ )가 발생한 영역은 높은 저항 영역으로 작용 하여, 급격한 열화를 유도해 전극 마모(electrode pitting)로 이어지게 된다 [7,10]. 그림 13은 전극 패터닝 유무에 따 른 타점 수가 증가함에 따라 판재와 전극 표면을 비교한 결과이다. 이때 표면 오염도는 20 타점까지 5타점 간격으 로 비교하였다. 일반전극을 사용한 경우, 5 타점부터 전극 과 판재의 표면에서 $\mathrm{Cu}-\mathrm{Al}$ 합금이 관찰되었다. 초기 합금 의 발생 위치와 크기는 타점별로 불규칙하게 발생하였고, 연속타점이 진행될수록 오염된 면적은 증가하였다. 반면에 패터닝된 전극에서는 15 타점부터 $\mathrm{Cu}-\mathrm{Al}$ 합금화가 전극 중심부에 발생하였다. 이는 격자 모양의 패턴 형상이 전극 -판재간 계면의 불균일한 산화특성을 완화하여 최대온도 감 소 및 국부적 발열 저감이 발생하였기 때문에 패터닝된 전

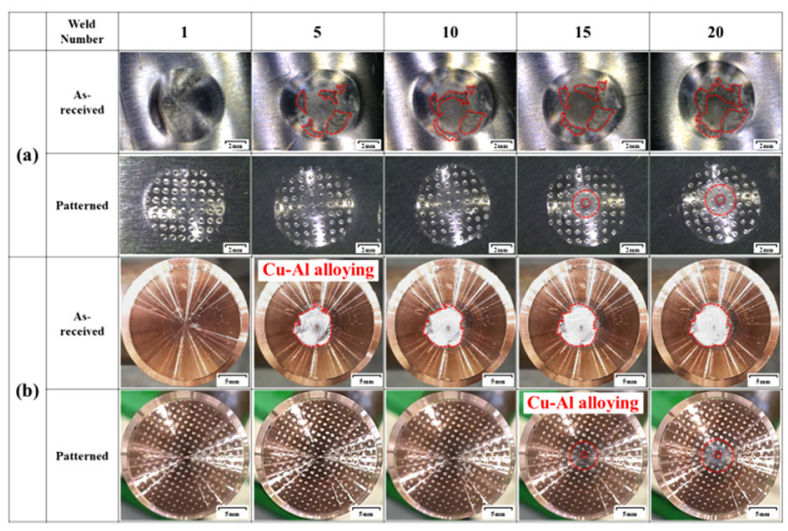

Fig. 13. Lower weld surface \& electrode surface morphology according to increasing weld number with respect to the electrode surface design; (a) weld surface, (b) electrode surface.

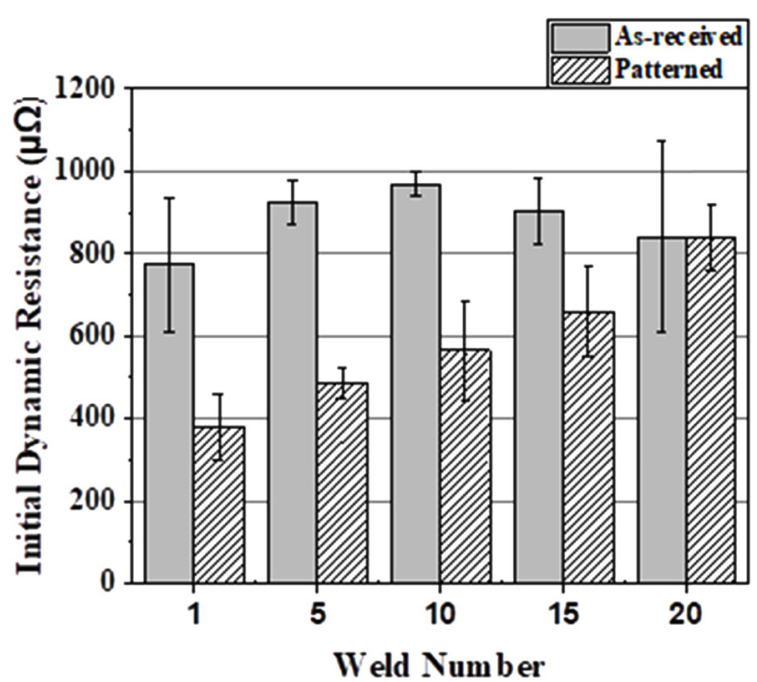

Fig. 14. Initial dynamic resistance at the beginning of welding during continuous RSW.

극의 연속 타점에서 열화가 지연되었다고 판단된다.

그림 14는 용접타점 증가에 따른 초기 동저항 값을 비 교한 결과이다. 모든 용접타점에 대해 패터닝된 전극의 초 기 동저항 값이 일반전극보다 낮았고, 10 타점까지는 평균 약 $1 / 2$ 의 차이를 보였다. 일반전극에서는 용접타점이 증 가함에 따라 초기 동저항 값은 평균 약 700-1000 $\mu \Omega$ 수 준인 반면, 패터닝된 전극에서는 용접타점이 증가할수록 초 기 동저항도 평균 약 $380 \mu \Omega$ 에서 $837 \mu \Omega$ 로 점차 증가 하였다. 초기 동저항 값은 모든 접합계면에 대한 접촉저항 의 영향이 우세하며, 일반전극에서는 알루미늄 합금의 표 면 산화층에 따른 불안정한 통전경로 인하여 1타점부터 높 은 초기 동저항 값으로 5 타점부터 합금화 현상이 발생한 것으로 판단된다. 반면에 패터닝된 전극에서는 전극-판재 간 계면에서 안정적인 통전면적 확보에 따른 일반전극의 약 $1 / 2$ 수준의 낮은 초기 동저항 값으로 인하여 합금화가 지연되었다고 판단된다. 즉, 전극-판재간 계면에서 픽업 $\rightarrow$ 합금화 융착현상이 진행됨에 따라 접촉저항 값은 상승하 며, 초기 동저항 값 변화를 이용하여 전극 표면의 합금화 에 따른 오염 및 융착상태를 추정 가능할 것으로 예상된다.

\subsection{2 용접부 너겟 직경 및 높이}

저항 점 용접부 품질을 결정짓는 인자 중의 하나인 용접 부 물성은 너겟의 직경 및 높이에 영향을 미치게 된다 [20]. 그림 15는 전극 패터닝 유무에 따른 연속타점의 용 접부 너겟의 직경 및 높이를 측정한 결과이다. 일반전극( 그림 $15(\mathrm{a})$ )으로 생성된 용접부의 너겟의 직경은 첫 번째 

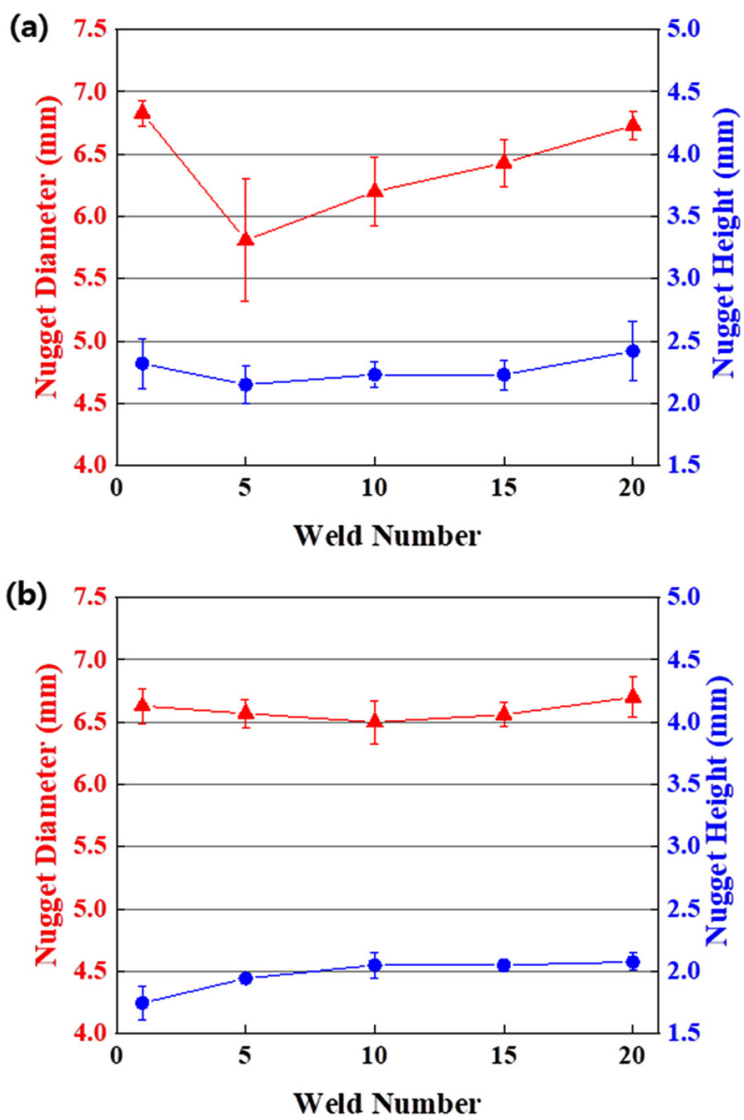

Fig. 15. Average weld nugget diameter and nugget height measurements during continuous resistance spot welding (RSW) as a function of electrode surface design; (a) as-received, (b) patterned.

타점에서 평균 $6.8 \mathrm{~mm}$ 가량으로 측정되었고, 5 타점에서는 $6 \mathrm{~mm}$ 미만으로 낮았다가 10타점 후 다시 증가하는 추세 를 보였다. 반면에 패터닝된 전극(그림 $15(\mathrm{~b})$ )으로 생성된 용접부의 너겟 직경은 1타점에서 20타점까지 평균 약 6.5 $\sim 6.8 \mathrm{~mm}$ 사이로 유사하게 관찰되었다. 일반전극으로 생성 된 용접부 너겟의 높이의 경우, 평균 약 $2 \sim 2.5 \mathrm{~mm}$ 사이로 측정되었고, 패터닝된 전극으로 생성된 너겟보다 평균 약 $0.3 \mathrm{~mm}$ 더 컸다. 너겟 직경 값에 대한 편차가 증가하는 원인은 패터닝 유무에 따른 접촉저항, 온도, 냉각 효과에 기인한 전극오염 및 합금화 정도 차이로 판단되며, 합금화 의 진행이 임계점 이상되면 매 타점마다 전극 표면 접촉현 상에 대한 차이로 인하여 용접부의 너겟 직경 및 높이에 영향을 미치는 것으로 사료된다 [7,14].

그림 16 은 연속타점 증가에 따른 용접부 $\mathrm{h} / \mathrm{t}$ 지수를 관 찰한 것이다. $\mathrm{h} / \mathrm{t}$ 지수는 저항 용접에서 발열현상 및 냉각 특성을 파악할 수 있는 간접적인 지수로써, 1 에 근접할수 록 용융되는 영역이 판재의 표면까지 도달한 것을 의미한 (a)
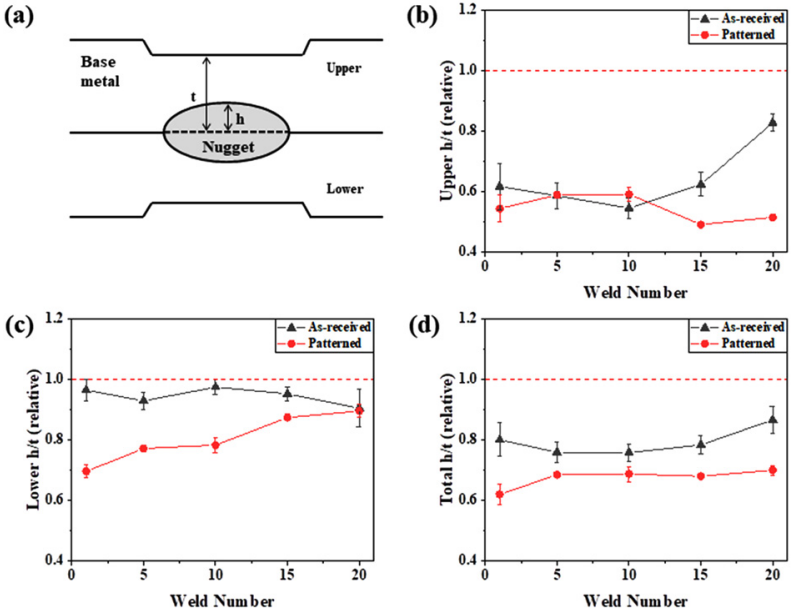

Fig. 16. The analysis of weldability according to continuous resistance spot welding (RSW) (a) Schematic of (b), (c), (d) h/t ratio.

다. 따라서 $\mathrm{h} / \mathrm{t}$ 지수를 통해 전극의 냉각능이 감소하거나, 전극-판재간 계면에서의 발열이 높은 것을 예상할 수 있다 [26]. 그림 16(a)는 용접부 단면 모식도이며, 압흔된 전극의 외각부에서 상부(또는 하부)판재 최하단부까지를 $\mathrm{t}$, 너겟 높 이를 $h$ 로 명명하였다. 펠티어 효과를 고려하여 상, 하부 전 극의 $\mathrm{h} / \mathrm{t}$ 지수를 그림 $16(\mathrm{~b})(\mathrm{d})$ 에 각각 나타내었다. 그림 $16(\mathrm{~b})$ 를 보면 10타점을 기준으로 $\mathrm{h} / \mathrm{t}$ 지수가 유사한 경향을 보이다가 20 타점에서 패터닝된 전극이 일반전극보다 평균 약 0.3 정도 낮았다. 하부(그림 16(c))의 경우, 용접타점 증가에 따라 $\mathrm{h} / \mathrm{t}$ 지수가 일반전극은 1 에 가까운 값으로 유 사하였고, 패터닝된 전극은 증가가였다. 그림 $16(\mathrm{~d})$ 는 상, 하부에 대한 평균 $\mathrm{h} / \mathrm{t}$ 지수를 나타낸 결과로 모든 용접타 점에 대한 $\mathrm{h} / \mathrm{t}$ 지수는 패터닝된 전극이 일반전극보다 더 낮았다. 앞서 그림 15 에서 연속타점에 대한 너겟의 직경 및 높이의 측정결과는 패터닝된 전극에서 훨씬 안정적이고 일정한 용접특성을 나타내었으며, 이는 패터닝된 전극이 전 극-판재간 계면의 낮은 발열을 유도하여 용접부 접합계면 에 입열을 집중시켰기 때문에 전극 열화에 따른 픽업 $\rightarrow$ 합 금화 $\rightarrow$ 융착현상은 지연되었다고 판단된다.

\subsection{3 전극 열화}

그림 17은 EPMA를 이용하여 20타점 후 전극 표면의 오염도를 분석한 결과를 나타내었다. 일반전극 표면(그림 17(a))에서는 고리 형태의 마모(ring pitting)가 관찰되었고, 이는 전단응력 대 압력 비에 의한 슬립거동이 전극의 중심 부 대비 주변부에서 더 많이 발생하였기 때문이다 [27]. 일반전극 표면의 낮은 $\mathrm{Cu}$ 성분 영역에서 $\mathrm{Al}$ 성분 및 $\mathrm{Si}$, 


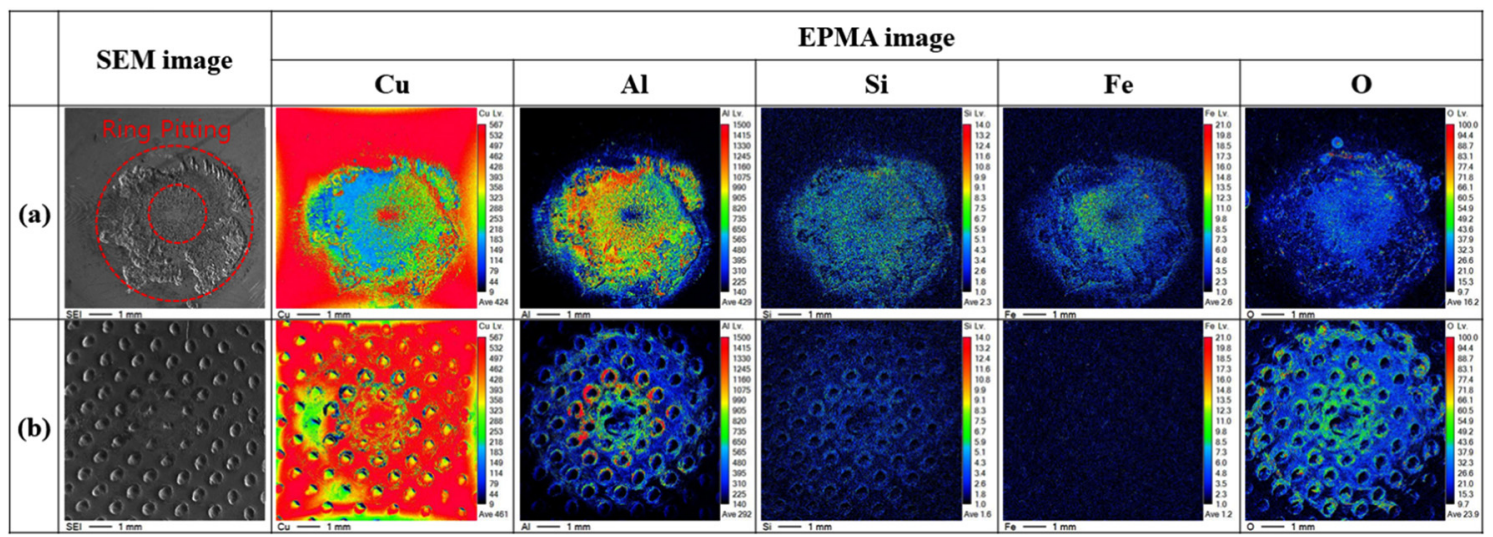

Fig. 17. The EPMA analysis of electrode surface after 20 weld count for electrode surface design; (a) as-received, (b) patterned.

$\mathrm{Fe}$ 성분이 검출되었다. 이는 $\mathrm{Cu}-\mathrm{Al}$ 합금화층의 알루미늄 기지 내 $\mathrm{Si}$ 와 $\mathrm{Fe}$ 성분이 일부 고용된 형태의 층이 존재하 는 것으로 판단된다 $[7,28]$. 반면에 패터닝된 전극 표면(그 림 $17(\mathrm{~b}))$ 에서는 $\mathrm{Al}$ 성분이 검출된 면적은 넓게 나타났으 나, 일반전극에 비해 $\mathrm{Si}, \mathrm{Fe}$ 성분은 거의 관찰되지 않았다. 일반적으로 $\mathrm{Si}, \mathrm{Fe}$ 성분들은 $\mathrm{Cu}$ 성분보다 융점이 높기 때 문에 $\mathrm{Cu}-\mathrm{Al}$ 합금화가 발생하는 온도보다 높은 수준의 온 도범위 도달해야만 한다 [29,30]. 본 연구의 앞선 결과를 통해 패터닝된 전극의 전극-판재 계면 발열온도가 일반전 극보다 낮은 결과를 확인하였으며, 고융점인 $\mathrm{Si}, \mathrm{Fe}$ 성분의 고용도가 낮았다고 판단된다. 또한 $\mathrm{O}$ 성분은 패터닝된 전 극에서 일반전극보다 넓은 면적으로 $\mathrm{Al}$ 성분의 면적과 유 사하였다. 이는 일반전극에서는 전극 표면에 $\mathrm{Cu}-\mathrm{Al}$ 합금화 가 많이 진행되어 안정적인 합금상으로 인하여 산화성이 낮은 반면[31], 패터닝된 전극에서는 합금화가 진행되지 않 은 알루미늄 픽업 영역에서 재용융 및 재산화되면서 알루 미늄 및 구리의 산화층 영역이 확대됨에 따라 $\mathrm{Al}$ 성분보 다 $\mathrm{O}$ 성분이 상대적으로 넓게 분포한 것으로 판단된다.

\section{5. 결 론}

본 연구에서는 격자 모양의 전극 패터닝 공법 적용을 적 용하여 접촉저항 및 동저항 거동, 발열 특성 비교·분석을 통해 용접부 단면 형상과 미세조직의 차이를 고찰하였고, 연속타점에 대한 전극과 판재 표면 오염도 및 합금화층 분 석을 통해 전극 패터닝이 너겟 형상 및 냉각 특성에 미치 는 영향에 대하여 연구하였으며, 다음과 같은 결론을 도출 하였다.

1) 전극 패터닝 유무에 따른 접촉저항 및 동저항을 비교 한 결과, 패터닝된 전극에서 저항이 더 작았다. 이는 격자
모양의 패턴 형상이 알루미늄 표면 산화층 붕괴를 유도하 여 통전면적 확장 및 전류 밀도 감소가 발생하였기 때문이 다. 또한 패터닝된 전극 사용 시 전극-판재간 계면의 발열 은 저감되고 판재-판재간 접합계면에 발열이 집중되어 발 열/냉각 특성이 향상되었다.

2) 용접부 미세구조를 관찰한 결과, 4 가지 영역이 형성 되었고 패터닝 유무에 따른 입열량과 냉각 속도의 차이로 인하여 수지상 영역의 분포가 달라졌으며, 빠른 냉각 속도 로 인하여 조성적 과냉도가 큰 패터닝된 전극에서 $\mathrm{EZ}$ 의 결정립은 미세화되고 2 차상의 분포는 감소하였다.

3) 연속타점에 대한 전극과 판재와 표면을 비교한 결과, 일반전극에서는 5 타점, 패터닝된 전극은 15 타점부터 $\mathrm{Cu}-\mathrm{Al}$ 합금화 현상이 관찰되었다. 또한 패터닝된 전극에서 용접 부 너겟이 판재-판재간 접합계면에 집중되었고, $\mathrm{h} / \mathrm{t}$ 지수가 0.7 이하의 값으로 일반전극보다 더 낮았다. 따라서 전극판재간 계면의 발열 현상의 차이로 전극 표면의 픽업 $\rightarrow$ 합 금화 $\rightarrow$ 융착현상에 따른 오염 정도가 달랐으며, 용접부의 너 겟 직경 및 높이, 전극 열화 특성은 변화하였다.

4) 전극 패터닝 유무에 따른 최종 용접타점의 전극 표면 $\mathrm{EPMA}$ 결과, $\mathrm{Cu}-\mathrm{Al}$ 합금화층 영역과 $\mathrm{Si}$ 와 $\mathrm{Fe}$ 성분의 고 용도에 차이가 발생하였으며, 이는 산화층 붕괴에 따른 접 촉저항 및 발열 저감이 원인으로 알루미늄 픽업 영역과 합 금화 영역을 구분하여 통전면적에 대한 산화특성의 차이를 확인하였다.

\section{ACKNOWLEDGEMENTS}

This study has been financially supported by the Ministry of Economy and Finance and conducted with the support of the Korea Institute of Industrial 
Technology as "Development of Smart Manufacturing Technology for Low Temperature Fuel Tank for LNG Ships project KITECH JA200009".

\section{REFERENCES}

1. K. Alexander, W. Daniel, and M. Marion, Phys. Procedia 56, 1410 (2014).

2. J. H. Kim, H. U. Jun, J. Y. Cheon, Y. D. Kim, and C. W. Ji, Korean J. Weld. Join. 38, 33 (2020).

3. Y. H. Oh, H. J. Ryu, T. Kim, M. Choi, and T. Lee, Korean J. Met. Mater. 57, 708 (2019).

4. L. Han, M. M. Thornton, D. Li, and M. Shergold, Mater. Des. 32, 2107 (2011).

5. H. Zhang, J. Senkara, and X. Wu, J. Manuf. Sci. Eng. 124, 79 (2002).

6. Y. Zhang, H. Shan, Y. Li, C. F. Zhao, Z. Luo, J. Guo, and C. Y. Ma, Int. J. Adv. Manuf. Syst. 92, 4231 (2017).

7. I. Lum, S. Fukumoto, E. Biro, D. R. Boomer, and Y. Zhou, Metall. Mater. Trans. A Phys. Metall. Mater. Sci. 35, 217 (2004).

8. Y. Kim, K. Y. Park, and K. D. Lee, Korean J. Weld. Join. 29, 1 (2011).

9. T. Ronnhult, U. Rilby, and I. Olefjord, Mater. Sci. Eng. 42, 329 (1980).

10. M. Rashid, S. Fukumoto, J. B. Medley, J. Villafuerte, and Y. Zhou, Weld. J. 86, 62 (2007).

11. K. R. Chan, and N. S. Scotchmer, Sheet Metal Welding Conference XIII, 5-3 (2008).

12. Z. Luo, S. Ao, Y. J. Chao, X. Cui, Y. Li, and Y. Lin, J. Mater. Eng. Perform. 24, 3881 (2015).

13. M. Mueller, H. Cramer, and T. Bschorr, Adv. Mat. Res. 814, 147 (2013).

14. L. Deng, Y. B. Li, B. E. Carlson, and D. R. Sigler, Weld. J. 97, 120 (2018).
15. Z. Li, C. Hao, J. Zhang, and H. Zhang, Weld. J. 86, 81 (2007).

16. H. U. Jun, J. H. Kim, J. Y. Cheon, Y. G. Kim, Y. D. Kim, and C. W. Ji, Korean J. Weld. Join. 38, 203 (2020).

17. Y. Zhang, H. Shan, Y. Li, C. F. Zhao, Z. Luo, J. Guo, and C. Y. Ma, Int. J. Adv. Manuf. Technol. 92, 4231 (2017).

18. M. Gao, and D. M. Rowe, Energy Convers. Manag. 41, 163 (2000).

19. S. Hassanifard, M. Zehsaz, and K. Tohgo, Strain. 47, 196 (2011).

20. A.M. Pereira, J.M. Ferreira, A. Loureiro, J. D. M. Costa, and P. J. Bártolo, Mater. Des. 31, 2454 (2010).

21. S. Kou, Welding metallurgy, p.431, New Jersey, USA (2003).

22. Y. Li, Z. Luo, F. Yan, R. Duan, and Q. Yao, Mater. Des. 56, 1025 (2014).

23. Y. Li, Y. Zhang, J. Bi, and Z. Luo, Mater. Des. 83, 577 (2015).

24. A. H. Ahmad, S. Naher, and D. Brabazon, Int. J. Automot. 9, 1685 (2014).

25. H. Y. Li, B. Jie, Y. K. Zhao, and X. F Wang, Trans. Nonferrous. Met. Soc. 21, 1944 (2011).

26. J. W. Kim, S. P. Murugan, N. H. Kang, and Y. D. Park, Korean J. Met. Mater. 57, 715 (2019).

27. M. Rashid, J. B. Medley, and Y. Zhou, Sci. Technol. Weld. Join. 14, 295 (2009).

28. C. W. Ji, I. Jo, H. Lee, I. D. Choi, Y. D. Kim, and Y. D. Park, J. Mech. Sci. Tech. 28, 4761 (2014).

29. L. M. Zhang, and R. Lück, Z. Metallkd. Int. J. Mater. Res. Adv. Tech. 94, 108 (2003).

30. B. Hallstedt, J. Gröbner, M. Hampl, and R. Schmid-Fetzer, Calphad. 53, 25 (2016).

31. G. Plascencia, T. Utigard, and T. Marín, JOM. 57, 80 (2005). 